\title{
"Miten varmistaa, että kukin iäkäs asukas on yleensä hengissä?" Taloyhtiötoimijoiden näkemyksiä ikäasumisesta
}

\author{
Suvi Fried ja Maiju Ratala
}

\section{Taustaa}

Monelle iäkkäälle kotona asuminen tarkoittaa asumista omassa kerrostalokodissa. Kerrostaloasunnossa asuu yli puolet 75 vuotta täyttäneistä yksinasuvista ja kolmasosa niistä kahden hengen talouksista, joissa ainakin toinen henkilö on täyttänyt 75 vuotta. Valtaosa, noin 80 prosenttia, 65 vuotta täyttäneistä asuu omistusasunnossa. (Ikääntyneiden asumisen toimenpideohjelma 2020.) Kerrostaloasuminen on merkittävä ikäasumisen ilmiö, ja kerrostaloja hallinnoivat taloyhtiöt ovat keskeisiä ikäasumisen toimijoita asumisen arjessa. Omistusasunnossa asuva asukas on samalla asuntoosakeyhtiön osakas, jolla on mahdollisuus vaikuttaa taloyhtiön päätöksiin.

Kuvaamme tässä kirjoituksessa syksyllä 2020 toteutetun pirkanmaalaisten taloyhtiöiden hallitusten jäsenille ja isännöitsijöille suunnatun ikäasumisen kyselyn tulokset ${ }^{1}$. Kyselyn tavoitteena oli selvittää taloyhtiötoimijoiden kokemuksia ikäasumisen arjesta ja ikääntymiseen liittyviä tiedon tarpeita. Suomalainen asunto-osakeyhtiö on kansainvälisesti poikkeuksellinen omistusasumisen ratkaisu (Juntto 2010), joten tätä tärkeää monialaista ilmiötä on tarpeellista tarkastella nimenomaan kotimaisessa keskustelussa.

Ikääntyvien kotona asumista ja asuinympäristöjä on viime aikoina tarkasteltu esimerkiksi liikkumisen mahdollisuuksien (Keskinen 2021) ja naapuruussuhteiden (Varjakoski
2021) näkökulmasta. Rappe ja kumppanit (2020) ovat puolestaan koonneet laajasti ikäasumisen eri toimijoita toimijaverkkoanalyysissaan. Järjestökentällä aihetta on käsitelty esimerkiksi Turvallisesti kotona -hankkeessa (Varsinais-Suomen Muistiyhdistys 2020), jossa on tuotettu materiaalia muistiystävällisestä taloyhtiöstä Taloyhtiöt ja muisti -sivustolle. Taloyhtiötoimijoille kohdistettua yleistä ikäasumisen kyselyä ei tietojemme mukaan ole kuitenkaan aikaisemmin toteutettu eikä aihetta koskevia tuloksia julkaistu.

Kyselyn aiheita olivat fyysistä ympäristöä koskevat ilmiöt, kuten esteettömyys, taloyhtiöiden sisäiseen vuorovaikutukseen liittyvät seikat ja suoraan vanhenemiseen liittyvät huomiot. Pyrimme avaamaan ja nostamaan esiin aiemmassa tutkimuksessa vähemmän esillä olleita aihepiirejä, kuten huolta hauraimpien asukkaiden selviytymisestä ja taloyhtiöissä ilmeneviä ristiriitoja. Kyselyn tuloksia käsitellään kolmen teeman kautta: taloyhtiöt fyysisenä ympäristönä, viestintä ja vuorovaikutus taloyhtiöissä sekä erilaiset ikääntyviä asukkaita koskevat huolet. Fyysiseen ympäristöön liittyviä huomioita olivat esteettömyyden lisäksi palveluntuottajien pysäköinti, apuvälineiden säilytys ja kotien siisteys. Viestintään ja vuorovaikutukseen liittyen nousi esiin muutamia ristiriitojen aiheita, jotka vaikeuttavat taloyhtiöiden yhteistoimintaa. Kyselyn vastaajat kuvailivat monenlaisia ikääntyviin asukkaisiin liittyviä huolia ja epävarmuutta huoli-ilmoituksen te- 
kemisessä. Osa huolista liittyy tasapainoiluun yksityisyyden kunnioittamisen ja keskinäisen huolenpidon välimaastossa.

\section{Aineisto}

Ikäasumisen kyselylinkki välitettiin Kiinteistöliitto Pirkanmaan jäsenille uutiskirjeen mukana, ja se oli auki 8.-31.10.2020. Uutiskirje lähetettiin sähköpostitse noin 4500 jäsenelle ${ }^{2}$, joista noin 43 prosenttia avasi kirjeen. Kyselyyn vastasi 179 henkilöä, mikä vastaa melko hyvin yhdistyksen jäsenkyselyn vastaajamäärää. Vastaajista 87 prosenttia oli taloyhtiön hallituksen jäseniä, 10 prosenttia isännöitsijöitä ja 2 prosenttia muita henkilöitä. Miehiä oli vastaajista 55 prosenttia ja naisia 44 prosenttia. Vastaajista 71 prosenttia oli täyttänyt 60 vuotta ja 36 prosenttia oli 70 vuotta täyttäneitä, mikä osoittaa, että seniorit ovat vahvasti mukana taloyhtiöiden päätöksenteossa. Yli puolet (58\%) vastaajista toimi Tampereella, minkä lisäksi vastauksia oli kolmestatoista muusta Pirkanmaan kunnasta.

Kysely $^{3}$ sisälsi monivalintakysymyksiä ja avoimia kysymyksiä, joissa omia vastauksia oli mahdollista tarkentaa. Kysymykset kohdistuivat talotekniikkaan, viranomaisyhteistyöhön, viestintään ja yhteydenpitoon sekä muihin omassa tehtävässä vastaan tuleviin ikääntymistä koskeviin erityisaiheisiin. Näitä aiheita olivat esimerkiksi esteettömyys ja ikääntyneeseen asukkaaseen liittyvä huoli. Vastaajilta kysyttiin myös heidän taustatietojaan, kuten ikää, sukupuolta ja tehtävää, jossa vastaaja toimii.

Selvä enemmistö eli 70 prosenttia vastanneista kertoi kohtaavansa tehtävässään ikääntymiseen liittyviä kysymyksiä tai yhteydenottoja. Heistä 56 prosenttia kohtasi kysymyksiä tai yhteydenottoja kerran vuodessa, 32 prosenttia kuukausittain ja 13 prosenttia viikoittain tai päivittäin. Lähes kaikki kyselyyn vastanneet isännöitsijät kertoivat kohtaavansa ikäasumisen kysymyksiä, ja he kohtasivat niitä myös muita vastaajia useammin. Yleisimmät teemat, joihin vastaajien kohtaamat kysymykset liittyivät, olivat viestintä ja yhteydenpito sekä ikääntymisen erityisaiheet.

Kyselyssä saatiin runsaasti avoimia vastauksia etenkin lopussa olleeseen avoimen palautteen kohtaan sekä kysymykseen, jossa vastaajat saivat kirjoittaa muista kohtaamistaan ikääntyneisiin asukkaisiin liittyvistä aiheista. Vastauksissa tuotiin esille esimerkiksi huolta ikääntyneestä asukkaasta, ikäystävällisen ympäristön merkitystä, asumisturvallisuuteen ja -terveyteen liittyviä seikkoja sekä viestinnän ja vuorovaikutuksen haasteita.

\section{Taloyhtiöt ikäasumisen fyysisenä ympäristönä}

Asuinympäristön esteettömyys on hyvin tunnistettu ikäasuminen osa-alue (esim. Vilkko ym. 2018). Esteettömyyden parantamisen pohdinnat nousivat esiin myös kyselymme vastauksissa. Vastaajista noin puolet oli kohdannut asuinympäristön esteellisyyteen ja noin kolmannes kodin muutostöihin liittyviä ikäasumisen kysymyksiä. Avovastauksissa keskityttiin pitkälti liikkumisympäristön esteettömyyteen, vaikka muisti- ja ikäystävällisen ympäristön ominaisuuksiin kuuluvat myös näkemisen ja kuulemisen tukeminen, selkeys ja hahmotettavuus, yhteisöllisyyden edistäminen sekä saavutettavuus kävellen (Rappe ym. 2018).

Monet vastaajat pitivät korjausten kustannuksia ongelmana, mutta toisaalta parannusten nähtiin myös nostavan taloyhtiön arvoa: "Tällä tavalla talo/osakkeet on myös houkutteleva myydä ja ostaa." Monet vastaajista toivoivat lisää tietoa ja koulutusta esteettömyydestä ja korjausneuvonnasta. Koulutusta kaipaavista vastaajista 67 prosenttia toivoi lisätietoa esteettömyydestä sekä siihen saatavista avustuksista ja 57 prosenttia korjausneuvonnasta. Tietoa korjausrakentamisen mahdollisuuksista ja saatavilla olevista avustuksista olisikin tarpeen levittää nykyistä tehokkaammin taloyhtiöille ja kansalaisille (Jolanki ym. 2020). 
Liikkumisen esteettömyyden lisäksi muutamat vastaajat nostivat esiin palveluntuottajien tarvitseman lyhytaikaisen pysäköintitilan sekä säilytystilan ikääntyneiden tarvitsemille liikkumisen apuvälineille. Eräs taloyhtiön hallituksen jäsen kuvasi tilannetta seuraavasti: "Kotihoidon henkilöstön pysäköinti on laitonta ja siihen pitäisi löytää ratkaisu. Ratkaisu ei ole se, että turvallisuuden vaarantavasta pelastusalueelle pysäköinnistä tehdään laillista jollain erityissäädöksellä, vaan se, että autolle löytyy erillinen varattu parkkipaikka. Meillä olisi siihen varaa, mutta miten saada ajatus läpi on eri asia."

Apuvälineiden säilytys yhteisissä tiloissa ei ole ongelmatonta. Kuoppa ja kumppanit (2020) käsitteellistävät tätä ilmiötä termillä toissijainen tila, joka voi tarkoittaa eteisiä, portaikkoja ja säilytystiloja. Toissijaiseen tilaan ei välttämättä ole kiinnitetty rakennusten suunnittelussa huomiota, vaikka ihmiset käyttävät niitä toistuvasti. Tällaisia tiloja saattavat olla eri elämänvaiheille erityisten tavaroiden ja asioiden organisoinnin, järjestämisen ja säilyttämisen tilat, ja niiden merkitys korostuu, jos ne eivät vastaa asukkaiden tarpeisiin. (Kuoppa ym. 2020.) Taloyhtiössä voi olla hankalaa edistää yhteisten tilojen soveltumista ikääntyneiden tarpeita vastaaviksi, jos muutosten koetaan palvelevan vain tiettyjä asukkaita.

Muutamissa avovastauksissa, joissa vastaajan oli mahdollista kirjoittaa muista ikääntymiseen liittyvistä aiheista, tuotiin esiin asumisterveyteen liittyviä ongelmia, kuten siivottomuus. Suomen Pelastusalan Keskusjärjestön (2019) kodin turvallisuuden tarkistuslistassa kodin järjestys on tunnistettu tärkeäksi aihepiiriksi tapaturmien ehkäisyn ja paloturvallisuuden kannalta. Siivottoman asunnon asukas on usein ikääntynyt ja muistisairas, ja siivottomuudella voi olla terveyshaittoja asukkaalle ja häiriötä myös naapureille. (Sosiaali- ja terveysalan lupaja valvontavirasto 2011.)

\section{Taloyhtiöiden sisäisen viestinnän ja vuorovaikutuksen ongelmat}

Miltei kaksi kolmannesta (65 \%) vastaajista kertoi kohdanneensa viestintään, yhteydenpitoon ja vuorovaikutukseen liittyviä ongelmia. Avovastauksissa oli yhteensä 22 tähän aihepiiriin liittyvää mainintaa, ja niissä yleisimmät aiheet olivat viestinnän sähköistyminen, sukupolvien väliset ristiriidat, ikääntyvien asukkaiden kriittisyys ja tiedonkulku yleensä.

Viestinnän sähköistymisen ongelmat tarkoittivat esimerkiksi taloyhtiöiden sähköisiä varausjärjestelmiä tai sähköpostin käyttöä yhteydenpitoon. Koronapandemian vuoksi järjestettyjen etäkokousten kerrottiin olleen osalle iäkkäitä osakkaita ja asukkaita haasteellisia. Tämän kyselyn vastaukset eivät anna tarkempaa tietoa etäkokouksiin siirtymisen vaikutuksista osallistumiseen. Sähköisten järjestelmien käytön ongelmat kuvattiin haluttomuutena tai kyvyttömyytenä oppia uudenlaisia yhteydenpidon tapoja. Kaikilla ei myöskään ollut tarvittavia laitteita sähköiseen yhteydenpitoon. Motivaation puute, oppimisen vaikeudet ja laitteisiin liittyvät ongelmat on tunnistettu yleisinä osallisuuden esteinä digitalisoituvassa yhteiskunnassa (Marston ym. 2019).

Taloyhtiöiden näkökulmasta tilanne näyttäytyy ristiriitaisena. Yhtäältä sähköisiin järjestelmiin siirtymisellä on monia kiistattomia hyötyjä. Toisaalta osakkaiden ja asukkaiden yhdenvertaisen osallistumisen mahdollistaminen on oleellinen osa taloyhtiöiden toimintaa. Erään vastaajan sanoin: "Aina ei muisteta, että netti ym. kanavat eivät tavoita kaikkia." Viestinnän näkökulmasta tärkeintä olisi pyrkiä luomaan taloyhtiön yhteisesti sovitut viestinnän tavat, joiden avulla yhteisten asioiden hoitaminen on mahdollista aidosti yhdessä.

Sukupolvien väliset ristiriidat yhdistettiin avovastauksissa osittain eri-ikäisten erilaisiin vuorovaikutustyyleihin ja toisaalta jyrkkiin näkemyseroihin taloyhtiön asioiden hoitamisesta. Eripuran arveltiin liittyvän myös iäkkäiden 
asukkaiden "piintyneisiin tapoihin" sekä "muutosvastarintaan ja itsekeskeiseen maailmankatsomukseen".

Sukupolvien väliset ristiriidat on tunnistettu ilmiö yhteiskunnassa, työpaikoilla ja yhteisöissä (Saarenheimo ym. 2014; Levy 2018), ja myös taloyhtiöissä kohdataan näitä ongelmia. Seuraavassa lainaus kuvaa ongelmien monia sävyjä: "Huoli siitä, että ikääntyvät eivät halua/jaksa osallistua hallitustyöhön, vaikka tuovat ongelmia/ehdotuksia esiin. Toinen ehkä vakavampi huoli siitä, että kommunikointi ikääntyneiden ja "nuorien" asukkaiden kesken on vaikeaa ja suorastaan riitaista jopa yhtiökokouksissa." Edellytyksiä myönteisten sukupolvien välisten kohtaamisten ja vuorovaikutustilanteiden syntymiselle olisivat Saarenheimon ja kumppaneiden (2014) mukaan keskinäinen arvostus, halukkuus kuulla toisen ikäisiä ja oppia heiltä sekä luontevasti yhdistävä toiminta.

Taloyhtiöiden hallitusten jäsenet kokivat ikääntyvien asukkaiden kriittisyyden turhauttavana. Yhteisten asioiden hoitaminen saatettiin kokea kuormittavana, koska tehtävän myötä he päätyivät kuuntelemaan asukkaiden valitusta. Iäkkäitä asukkaita kuvattiin esimerkiksi termillä "ns. äänekkäät valittajaseniorit" ja heidän puhetapaansa "räpätykseksi”. Näitä kuvauksia voi tarkastella monesta tulkintakehyksestä. Voi olla niin, että on vanhoja ihmisiä, jotka valittavat äänekkäästi ja puhuvat"räpättävään" tapaan. Toisaalta kuvauksilla voidaan pyrkiä vähättelemään vanhojen ihmisten kommentteja ja huomioita taloyhtiön asioista (vrt. ikäsyrjintä esim. Levy 2018), ja niihin voivat vaikuttaa kielteiset kulttuuriset käsitykset ikääntyneistä (Varjakoski 2021).

Vanhojen ihmisten valittamiselle löytyy tulkintaehdotuksia myös kirjallisuudesta. Westin ja kumppanien (2017) mukaan ikäihmisten valittamisessa ei ole kyse vain asiantilan kuvaamisesta, vaan valittaminen voi olla erilaisten omakohtaisen elämänkulullisten siirtymien ilmenemistapa. Alemán (2001) puolestaan tulkitsee valittamisen olevan oman itsenäisyyden ja avuntarpeen välisten jännitteiden ilmaisua. Näiden tulkintaehdotusten valossa joissakin tilanteissa tärkeintä lienee myötäelävä kuunteleminen, ei niinkään ratkaisujen löytäminen. Samaan aikaan on tärkeää tunnistaa ne tilanteet, joissa iäkkään asukkaan kriittisyys ja valitus on perusteltua ja esitettyihin ongelmiin on olemassa taloyhtiön toimialaan kuuluvia ratkaisuja.

Tiedonkulun haasteiden kirjo oli avovastauksissa moninainen. Muutamassa vastauksessa pohdittiin, miten saisi tiedon siitä, että kaikilla asukkailla on asiat hyvin. Yhdessä vastauksessa ehdotettiin jopa "painonappia",jonka avulla iäkäs asukas voisi aamulla ilmoittaa olevansa kunnossa. Kahdessa vastauksessa pohdittiin, miten asukkaan kuolemasta saa tiedon. Osa ikääntyneistä asuu niin itsenäisesti, ettei heidän luonaan vierailla säännöllisesti. On myös iäkkäitä asukkaita, jotka kieltäytyvät avusta, ja vastauksissa pohdittiin henkilökohtaisiin asioihin puuttumisen kynnystä ja sitä, voiko omaisiin olla yhteydessä.

Edellä kuvattu huoli siitä, että iäkkäimpien asukkaiden kriittinen avuntarve jää huomaamatta, ilmentää kerrostalonaapuruuden eristyneisyyttä. Kerrostaloissa naapurien on hankalampi seurailla esimerkiksi toistensa valojen syttymistä ja sammumista kuin pientalojen naapurustoissa. Toisaalta naapureiden yksityisyyden kunnioittamiseen kuuluu sekin, ettei toisten tekemisiä ja liikkeitä seurata liian tarkkaan (Haverinen \& Kouvo 2011).

Yhdessä muista poikkeavassa vastauksessa nostettiin esiin iäkkäiden asukkaiden toive keskustelutuokioista, joissa välitettäisiin rauhallisesti ajankohtaista tietoa taloyhtiön asioista. Lisäksi koulutusta kaipaavista noin puolet toivoi lisätietoa yhteisöllisen toiminnan vahvistamisesta taloyhtiössä. Järjestöjen tuottaman yhteisöllisyyttä vahvistavan toiminnan yhteydessä on esimerkiksi huomattu keskinäisten suhteiden vahvistumista ja sen myötä parempaa talon sisäistä yhteydenpitoa. Tuttuus edistää myös naapuriavun saamista (Varjakoski 2021). 


\section{Taloyhtiötoimijoiden huoli iäkkäistä asukkaista}

Kyselyssä oli oma kohtansa ikääntymisen erityiskysymyksille, kuten iäkkäitä asukkaita koskeville huolille. Avoimissa vastauksissa toistuivat erityisesti muistiin, yksinäisyyteen ja toimintakyvyn muutoksiin liittyvät huomiot. Muistiongelmien huomaamiseen liitettiin joissakin vastauksissa suoranainen huoli asukkaan kyvystä asua turvallisesti yksin. Toisella tapaa turvallisuuteen liittyi puolestaan pelastuslaitoksen toimintamahdollisuuksien pohtiminen vaaratilanteessa. Ehditäänkö ajoissa paikalle pelastustoimiin, kun hauras asukas on vaarassa omassa asunnossaan?

Yksin asuvan iäkkään asukkaan kohdalla huoli ei näyttänyt kohdistuvan yksinäisyyden kokemukseen sinänsä vaan siihen, ettei yksin asuvalla asukkaalla ole välitöntä tukea, jos hän tarvitsee apua. Yksin asumisen riskit koskevat yleisellä tasolla kaikkia ikäryhmiä, mutta ikääntyvän henkilön yksin asuminen vaikuttaisi herättävän huolta naapureissa. Tämä voi liittyä siihen, että avun tarpeen huomaaminen ja siihen reagoiminen tuntuu jäävän naapurin vastuulle. Naapureiden merkitys korostuu, jos sukulaisia ei ole tai jos he asuvat kaukana, sekä satunnaisissa tuen tarpeiden tilanteissa ja hätätilanteissa (Varjakoski 2021).

Sukulaisten vierailut ikääntyneen luona eivät välttämättä lievitä ikääntyneen arkea läheltä seuraavan naapurin huolta:"Osa senioreiden sukulaisista käy vain pikaisesti, eikä sukulaisilla välttämättä tämän takia ole samanlaista tietoa seniorin arjesta kuin esim. naapureilla." Eräs taloyhtiön hallituksen jäsen kuvaili omaisia välinpitämättömiksi ja jatkoi:"Asukkaat joutuvat tavallaan huolehtimaan omaisista. Heitä pidetään liian pitkään yksin asumassa vaikkei edellytyksiä siihen ei olisi enään.”

Konkreettinen ratkaisu taloyhtiön hallituksen jäsenten huoliin on vanhuspalvelulaissa (Laki ikääntyneen... 980/2012, §25) kuvattu huoli-ilmoitus. Sen voi tehdä kuka tahansa viranomaiselle vanhasta ihmisestä, jonka selviytymisestä on huolissaan. Osalla vastaajista oli tietoa huoli-ilmoituksesta, mutta monista vastauksista välittyi epävarmuus ilmoituksen tekemisen oikea-aikaisuudesta, esimerkiksi näin: "Kun seniorilla on paha olo, on sairautta ja yksinäisyyttä, keneen hänet ohjataan ottamaan yhteyttä. En tunnista, onko se huoli-ilmoituksen piiriin kuuluvaa. Se, että senioreiden toivotaan kykenevän olemaan kotona mahdollisimman pitkään, lisää taloyhtiöiden hallitusten kuormitusta liikaa eikä näin todellakaan tarvitsisi olla."

Muutamassa vastauksessa pohdittiin omia mahdollisuuksia vaikuttaa asukkaan palveluiden saamiseen ja palveluiden saatavuutta ylipäätään. "Haluaisin tietää, voiko [taloyhtiön] hallitus esimerkiksi yhteydenotollaan vaikuttaa siihen, että seniorin laitospaikan saaminen mahdollisesti nopeutuisi? [...] Osa kotona asuvista on tavalla tai toisella niin huonokuntoisia tai muuten esim. aggressiivisia, että eivät pärjää enää kotonaan. Ts. millä muulla tavoin taloyhtiö voi edesauttaa senioreiden asioita kuin kuunnella haukkuja?” Taloyhtiön hallituksen resurssit koettiin rajallisina suhteessa avun tarpeeseen: "Ikääntyvät ihmiset tarvitsevat monenlaista tukea pystyäkseen asumaan pidempään nykyisessä kodissaan. Taloyhtiön hallituksella ei ole välttämättä riittävästi tietoa tällaisen tuen tarjoamiseen." Onko näissä kuvauksissa itse asiassa kyse hoivaköyhyydestä eli riittämättömästä hoivasta suhteessa olemassa oleviin tarpeisiin (Kröger ym. 2019)?

Koulutusta kaivanneista 56 prosenttia toivoi lisätietoa vanhustyöstä, kuten huoli-ilmoituksesta, ja 46 prosenttia toivoi lisätietoa muistisairaan kohtaamisesta. Huoli-ilmoituksesta on viime vuosina pyritty viestimään, ja monilla kaupungeilla ja kunnilla on verkkolomake ilmoituksen tekemiseen. Käytännöt kuitenkin vaihtelevat kunnittain, eikä viestintä ole vielä tavoittanut kansalaisia laajasti. 


\section{Lopuksi}

Kyselyn tulosten perusteella voidaan todeta, että taloyhtiötoimijoilla, erityisesti hallitusten jäsenillä ja isännöitsijöillä, on merkityksellinen rooli osana ikääntyneiden asumisen toimijaverkkoa (Rappe ym. 2020). Rappen ja kumppanien (2020) toimijaverkon kuvaus kohdistuu muistisairaan hyvään asumiseen, mutta se on sovellettavissa monen muunkin iäkkään tilanteeseen. Naapurit ovat puolestaan tärkeä osa ikääntyneiden sosiaalisia verkostoja, ja heidän merkityksensä korostuu ikääntymisen myötä (Varjakoski 2021). Havainnot taloyhtiöistä ikäasumisen sosiaalisena ympäristönä nousivat kyselyn vastauksissa vahvasti esiin. Kotona asuminen hyvinkin hauraana tarkoittaa sitä, että osa ikääntymiseen liittyvistä vaativista huolista on nyt omaishoitajien, läheisten ja naapuruston, jopa taloyhtiön kannettavana.

Taloyhtiöiden hallituksissa kaivataan edelleen lisää tietoa fyysisen ympäristön esteettömyyden edistämisestä. Taloyhtiöt ovat toimijoita, joilla on konkreettinen mahdollisuus vaikuttaa oman ympäristönsä muisti- ja ikäystävällisyyteen. Liikkumisen esteettömyyden lisäksi tarvittaisiin tietoa myös muista ikäystävällisistä parannuksista asuinympäristöön. Lähes puolet (47\%) kaikista vastaajista kertoi kaipaavansa lisää ammatillista tukea tai koulutusta ikäasumisen ratkaisuista. Tärkeää olisi tehdä parannusten hyödyt näkyviksi myös muille asukkaille, jotta ikäystävällisyyttä olisi mahdollista edistää taloyhtiössä.

Kyselyn tulokset osoittivat selkeitä tiedontarpeita. Jatkossa olisikin tärkeää, että vanhustyöstä suunnattaisiin entistä tehokkaampaa viestintää kiinteistötoimijoille. Huoliilmoitus on yksi konkreettinen väline ongelmatilanteisiin, mutta kyselyn mukaan se tunnetaan vielä huonosti ja ilmoituksen tekemistä epäröidään. Huoli-ilmoituksesta viestiminen on ensisijaisesti kunkin kunnan tehtävä, mutta esimerkiksi etsivän vanhustyön tekijät järjestöissä ovat viestineet siitä aktiivisesti (esim.
Askeleet etsivään vanhustyöhön -kortit 2019; Ikäystävällinen taloyhtiö -esite).

Taloyhtiötoimijoille suunnatun ikäasumisen kyselyn tulokset paljastivat toimijoiden kokemuksia monista hankalista asioista. Vastauksissa ilmaistiin myös motivaatiota ikäasumisen kehittämiseen, kuten eräs isännöitsijä kuvailee: "Haluaisin olla kehittämässä turvallisempaa asumisympäristöä ikääntyville, kaikki kun ei hoitolaitoksiin halua ja väestö ikääntyy, joten tämä ei ole vain tämän hetken juttu.”

\section{Yhteydenotto:}

Suvi Fried, sh, TtM, HTM

suvi.fried@gmail.com

\section{Viitteet}

1 Kysely toteutettiin osana Markku-matkaava päiväpalvelu -hanketyötä (Sopimusvuorisäätiö/STEA 2018-2021) yhteistyössä Kiinteistöliitto Pirkanmaa ry:n kanssa. Markku-hankkeen työtä tehtiin tiiviissä yhteistyössä iäkkäiden ja muutaman taloyhtiön sekä vuokratalotoimijan kanssa. Kehittämistyö kohdistui iäkkäiden yhteisöllisyyden vahvistamiseen kotipiirissä toteutettavan kohtaamispaikkatoiminnan avulla.

2 Uutiskirjeen vastaanottajista noin 3000 on taloyhtiön hallituksen puheenjohtajia, noin 500 muita hallituksen jäseniä ja noin 500 isännöitsijöitä.

3 Kyselyn kysymykset löytyvät verkkosivulta https://innokyla.fi/fi/toimintamalli/ikaystavallinen-taloyhtio

\section{Kirjallisuus}

Alemán MW. Complaining among the elderly: examining multiple dialectical oppositions to independence in a retirement community. West J Commun 2001;65(1):89-112. https://doi:10.1080/10570310109374693

Askeleet etsivään vanhustyöhön -kortit. Helsinki: Valli ry, 2019. Internet: https://www.valli.fi/ wp-content/uploads/2020/02/Julkaisut_Navigaatiokortit2.pdf (viitattu 22.7.2021).

Haverinen R, Kouvo A. Milloin naapurin asiat kuuluvat sinulle? Naapurihäiriöihin puuttuminen ja niihin mukautuminen. Yhdyskuntasuunnittelu 2011;49(2):8-27.

Ikäystävällinen taloyhtiö -esite. Tampere: Markkumatkaava päiväpalvelu -hanke (2018-2021), So- 
pimusvuorisäätiö, 2021. Internet: https://innokyla.fi/sites/default/files/2021-07/Ikaystavallinen_taloyhtio_esite.pdf (viitattu 22.7.2021).

Ikääntyneiden asumisen toimenpideohjelma 20202022. Helsinki: Ympäristöministeriö, 2020.

Jolanki O, Suhonen R, Rappe E. Hyvinvointia ja osallisuutta asuinympäristöjä kehittämällä. Gerontologia 2020;34(4):349-53.

Juntto A. Asumisen historiallinen muutos Suomessa ja polkuriippuvuus. Teoksessa: Juntto A, toim. Asumisen unelmat ja arki: suomalainen asuminen muutoksessa. Helsinki: Gaudeamus, 2010:17-47.

Keskinen K. Features of the physical environment, walking difficulty, and physical activity in old age. Jyväskylä: University of Jyväskylä, 2021.

Kröger T, Puthenparambil JM, Aerschot LV. Care poverty: unmet care needs in a Nordic welfare state. International Journal of Care and Caring 2019;3(4):485-500. https://doi.org/10.1332/239 788219X15641291564296

Kuoppa J, Saarimaa S, Ruoppila S, Laine M, Nieminen N, Haverinen R. Houkuttelevan asumisen ainekset. Yhdyskuntasuunnittelu 2020; 58(29):1032. https://doi.org/10.33357/ys.95604

Laki ikääntyneen väestön toimintakyvyn tukemisesta sekä iäkkäiden sosiaali- ja terveyspalveluista 28.12.2012/980.

Levy SR. Toward reducing ageism: PEACE (Positive Education about Aging and Contact Experiences) model. Gerontologist 2018;58(2):226-32. https://doi.org/10.1093/geront/gnw116

Marston HR, Genoe R, Freeman S, Kulczycki C, Musselwhite C. Older adults' perceptions of ICT: main findings from the Technology In Later Life (TILL) study. Healthcare 2019;7(3):e86. https://doi:10.3390/healthcare7030086
Rappe E, Kotilainen H, Rajaniemi J, Topo P. Muisti- ja ikäystävällinen asuminen ja asuinympäristö. Ympäristöopas. Helsinki: Ympäristöministeriö, 2018.

Rappe E, Rajaniemi J, Topo P. Hyvä asuminen muistisairaana. Gerontologia 2020;34(2):135-54.

Saarenheimo M, Pietilä M, Maununaho S, Tiihonen A, Pohjolainen P.Ikäpolvien taju - Elämänkulku ja ikäpolvet muuttuvassa maailmassa. Helsinki: Vanhustyön keskusliitto, 2014.

Sosiaali- ja terveysalan lupa- ja valvontavirasto. Valviran ohje asuntojen siivottomuustapauksissa. Ohje viranomaisille 3/2011. Helsinki: Valvira, 2011.

Suomen Pelastusalan Keskusjärjestö. Kodin turvallisuuden tarkistuslista. 2019. Internet: www.issuu. com/spek_ry/docs/kodin_turvallisuuden_tarkistuslista (viitattu 1.7.2021).

Varjakoski H. Ikääntyneiden naapurisuhteista ja -verkostoista. Gerontologia 2021;2:193-203. https://doi.org/10.23989/gerontologia.98638

Varsinais-Suomen Muistiyhdistys. Taloyhtiöt ja muisti. 2020. Internet: https://www.muistiturku. fi/fi/muisti-ja-muistisairaudet/arjen-turvallisuus/ taloyhtiot-ja-muisti/ (viitattu 1.7.2021).

Vilkko A, Sainio P, Hammar T, Vainio S. Asuinympäristö. Teoksessa: Koponen P, Borodulin K, Lundqvist A, Sääksjärvi K, Koskinen S, toim. Terveys, toimintakyky ja hyvinvointi Suomessa. FinTerveys 2017 -tutkimus. Raportti 4/2018. Helsinki: THL, 2018:169-74.

West K, Shaw R, Hagger B, Holland C. Enjoying the third age! Discourse, identity and liminality in extra-care communities. Ageing Soc 2017;37(9):1874-97. https://doi:10.1017/S0144686X16000556 